\title{
Comparison of wheat growth-response to endophytic Beauveria bassiana (Hypocreales: Cordycipitaceae) derived from an insect versus plant host
}

\author{
Lisemelo F. Motholo ${ }^{1,2}$, Mardé Booyse ${ }^{3}$, Justin L. Hatting ${ }^{1 *}$, Toi J. Tsilo ${ }^{1}$, Oriel M. M. Thekisoe ${ }^{2}$ \\ ${ }^{1}$ Agricultural Research Council - Small Grain, Private Bag X29, Bethlehem, 9700, South Africa \\ ${ }^{2}$ Unit for Environmental Sciences and Management, North-West University, Private Bag X6001, Potchefstroom, \\ 2520, South Africa \\ ${ }^{3}$ Agricultural Research Council - Biometry, Private Bag X5013, Stellenbosch, 7599, South Africa
}

*Corresponding author: HattingJ@arc.agric.za

\begin{abstract}
Beauveria bassiana (Hypocreales) is a cosmopolitan entomopathogen, infecting $>700$ insect species. Although traditionally associated with insects, endophytic colonisation of plants is also known. Endophytism may protect plants against insects/diseases and enhance plant growth. Both insect- and plant-derived (endophytic) 'sources' of B. bassiana may be present in an agroecosystem, both of which may be in contact with plants. Here, growth response, viz., root length, shoot height, fresh root biomass, fresh and dry shoot biomass of wheat, Triticum aestivum L. (Poaceae), is reported following inoculation with $B$. bassiana (strain PPRI 7598). The strain was passaged and re-isolated from an insect (IN) versus plant (PL) substrate. When five wheat cultivars were inoculated with either B. bassiana PPRI 7598IN or -PL isolates through seed imbibition, a significantly higher level of endophytism (roots, stems and leaves, combined) was recorded with 7598IN (29.74\%) compared to 7598PL (26.13\%). Cultivar Baviaans responded best to endophytic colonisation (plant parts combined) at $33.54 \%$, followed by Tugela (31.34\%), Kariega (27.87\%), Gariep (25.67\%) and Elands (21.28\%). On average, B. bassiana-treated plants showed a $71 \%$ growth increase over control plants. In topically sprayed bioassays, $7598 \mathrm{IN}$ caused $57 \%$ mortality to Russian wheat aphid, Diuraphis noxia, compared with $50 \%$ by 7598PL; also recording a significantly shorter mean time to aphid mortality (4.14 days) versus 7598PL (4.58 days). A significantly higher level of overt mycosis (58.2\%) was noted with 7598IN compared with 7598PL (47.9\%). Results underscored several positive aspects associated with endophytic $B$. bassiana in wheat, creating new and exciting IPM possibilities.
\end{abstract}

Keywords: Beauveria bassiana; Diuraphis noxia; endophyte; plant colonisation; plant growth response; Triticum aestivum. Abbreviations: EPF_Entomopathogenic fungi, IPM_Integrated pest management, PHS_Pre-harvest sprouting, SA_South Africa, ARC_Agricultural Research Council, RWA_Russian wheat aphid, FHB_Fusarium head blight, SDAY_Sabouraud dextrose agar with yeast, CBC_Conservation Biological Control, DPI _Days post inoculation, LSD_Least significant differences, HPR_Host plant resistance

\section{Introduction}

In South Africa, wheat, Triticum aestivum L. (Poaceae), is prone to infestation by at least six cereal aphid (Homoptera: Aphididae) species, of which the Russian wheat aphid (RWA), Diuraphis noxia, is considered the most damaging (Prinsloo and Tolmay, 2015). Host plant resistance (HPR) currently forms the backbone of RWA control under dryland conditions in the summer rainfall region. However, since the arrival of the first aphid biotype, RWASA1 in 1978, four subsequent biotypes, RWASA2, RWASA3, RWASA4 and RWASA5 made their appearance in 2005, 2009, 2011 and 2018, respectively (Jankielsohn, 2016, 2019). The development of aphid biotypes is not unexpected, as widespread deployment of HPR implies evolutionary adaptation, fueled by a higher selection pressure (Smith and Chuang, 2014; Yates and Michel, 2018). To counteract such selection, indiscriminate mortality inflicted by natural enemies (predators, parasitoids and pathogens), is seen as a critical component in a HPR x natural enemy-based control programme (Sunderland et al., 1988; Marasas et al., 1997). The natural enemy complex associated with RWA in South Africa is diverse, inclusive of both endemic and (classically) introduced species (Hatting, 2002; Prinsloo et al., 2002). The impact of entomopathogenic fungi (EPF) on cereal aphid populations is of particular importance, especially epizootics induced by Pandora neoaphidis (Entomophthoromycota: Entomophthorales) (Hatting et al., 2000). Although EPF grow in culture medium, the fastidious nature of the Entomophthoromycota renders fungal spores a difficulty to mass produce/formulate into commercial mycoinsecticides. On the other hand, the highly amenable EPF, Beauveria bassiana (Hypocreales: Cordycipitaceae), is also known to naturally infect RWA in South Africa (Hatting et al., 1999), albeit at a low prevalence (Hatting et al., 2000). Integration of $B$. bassiana (topical applications) against RWA in combination with HPR, was explored by Hatting et al. 
(2004); finding around 65\% fewer aphids in treated field plots compared with controls. Locally, application of $B$. bassiana on various crop commodities has been based on an augmentative approach (Hatting et al., 2018), similar to that of a chemical paradigm. However, the ubiquitous nature of this EPF within global agro-ecosystems, makes it suitable for exploitation in Conservation Biological Control (CBC) (Fuxa, 1998), as proposed by Meyling and Eilenberg (2007). Therefore, the notion of exploiting $B$. bassiana in a $\mathrm{CBC}$ approach carries relevance, not only in terms of insect suppression, but potentially for disease suppression (Busby et al., 2016) and also as a plant growth-promoting factor (Behie and Bidochka, 2014; Sánchez-Rodríguez et al., 2015; Liao et al., 2017; Jaber and Enkerli, 2017; Sánchez-Rodríguez et al., 2018). In nature, insect-derived inoculum is the primary source of $B$. bassiana, while the historical frequency of recycling remains largely unknown. Host plant contact with such inoculum can be via seed/roots in the soil environment [see Zimmerman (2007) for a list of worldwide soil extractions] and/or via above ground phylloplanes (Meyling and Eilenberg, 2006; Howe et al., 2016).

Beauveria bassiana can be linked to three basic associations, namely soil, insects and/or plants (Meyling and Eilenberg, 2007). In the latter association, the fungus may exist as an endophyte (Vega, 2008). In the endophytic state, there is potential to exploit the fungus for induced systemic resistance to biotic and/or abiotic stressors (Rodriguez et al., 2009). Moreover, as a host plant, T. aestivum appears endophytic-friendly, both as natural host (Crous et al., 1995; Larran et al., 2002, 2007; Vujanovic et al., 2012; Comby et al., 2016; Grudzinska-Sterno et al., 2016) and when artificially inoculated (Dingle and McGee, 2003; Gurulingappa et al., 2010; Russo et al., 2015; SánchezRodríguez et al., 2015; Sánchez-Rodríguez et al., 2018).

In a recent review on EPF as endophytes in biological control, Vega (2018) found that $40 \%(34 / 85)$ of papers covered examined plant responses to endophytism, covering 20 plant species. In that review, generally, the use of different inoculation techniques to inoculate plants resulted in colonisation of plants. The current study is the first to investigate the growth-response of five South African wheat cultivars to endophytic $B$. bassiana (strain 7598; originally extracted from a soil sample), passaged through an insect versus plant substrate (Russian wheat aphid, Diuraphis noxia versus $T$. aestivum, respectively). Three inoculation techniques were employed to simulate potential contact mechanisms possible under field conditions.

\section{Results}

Endophytic colonisation of wheat (inoculation of seeds through imbibition)

Beauveria bassiana was never re-isolated from 'control' plants in any experiment. The level of endophytic colonisation varied significantly among cultivars $\left(F_{4,90 ; 0.00}=\right.$ 24.81), between fungal isolates (PPRI 7598IN Vs PPRI 7598PL; $F_{1,90 ; 0.00}=17.48$ ), among plant parts (root, stem and leaf; $F_{2,90 ; 0.00}=106.90$ ) and between evaluation times (7 vs $\left.14 \mathrm{DPI} ; \mathrm{F}_{1,90 ; 0.00}=168.15\right)$. The most colonised cultivar (combined plant parts; $\mathrm{n}=96$ per cultivar; $\mathrm{LSD}_{0.05}=4.44$ ) was Baviaans (33.54\%), followed by Tugela (31.34\%), Kariega
(27.87\%), Gariep (25.67\%) and Elands (21.28\%). A significantly higher $(P<0.05)$ level of colonisation (plant parts combined) was recorded with PPRI 7598IN (29.74\%; $n=240$ ) compared with PPRI 7598PL (26.13\%; $n=240)$. The highest level of colonisation (44.15\%) was recorded in roots with PPRI $7598 \mathrm{IN}$ at $7 \mathrm{DPI}$, statistically outperforming all other treatments (Fig.1). Generally, leaf colonisation was low, ranging from $12 \%$ to $28 \%$. Recovery of $B$. bassiana showed a general decline from 7 - 14 DPI for all treatments.

\section{Effect of three inoculation techniques on plant growth of five wheat cultivars}

On average, treated plants showed a $71 \%$ growth increase over controls, with mean growth parameter responses ranging from $29 \%$ to $104 \%$ (Table 2). Although seed imbibition ranked first (mean improvement of $87.8 \%$ ) among the three inoculation techniques employed (Table 2), leaf spraying resulted in a more consistent, high level of plant response, ranking first for four of the five parameters, viz., fresh shoot biomass, dry shoot biomass, root length and shoot height (Table 2). There were significant differences among the cultivars for three of the five parameters measured, viz., dry shoot biomass $\left(F_{4,90 ; 0.00}=3.75\right)$, fresh root biomass $\left(F_{4,90 ; 0.00}=68.66\right)$ and root length $\left(F_{4,90 ; 0.02}=3.10\right)$, but not for shoot height $\left(F_{4,90 ; 0.06}=2.31\right)$ and fresh shoot biomass $\left(F_{4,90 ; 0.11}=1.91\right)$. However, when pairwise comparisons were performed among the cultivars for shoot height and fresh shoot biomass, the Fisher's unprotected LSD test (Hsu, 1996) did indicate differences. This variation is further emphasized by the fact that for each growth parameter, a different cultivar ranked first (Table 3 ). Of particular interest was cultivar Kariega, showing a $260 \%$ increase in fresh root biomass (inoculation techniques combined), far exceeding the second-best responder (Gariep) at $81 \%$. When considering the fresh root biomassresponse of cultivar Kariega, by inoculation technique, seed imbibition significantly outperformed leaf spraying and soil drenching at $+672 \%,+54 \%$ and $+7 \%$, respectively $\left(\operatorname{LSD}_{0.05}=\right.$ 52.15).

\section{Virulence of Beauveria bassiana PPRI 7598 to RWA following passage and re-isolation from an insect ('IN') versus plant ('PL') host}

The conidial depositions (estimated number of propagules deposited per square millimeter on an agar plate; counted at 40x magnification using the light microsope) for PPRI 7598IN and $-\mathrm{PL}$, were $1820 \pm 68$ conidia $\mathrm{mm}^{-2}$ and $1958 \pm 60$ conidia $\mathrm{mm}^{-2}$, respectively. During these assays, the insect-derived versus plant-derived isolates caused respective aphid mortalities of $57 \%$ versus $50 \%, 7$ days post inoculation; albeit not significantly different at the $5 \%$ test level with LSD of 7.56. (Fig. 2). Moreover, the insect-derived isolate recorded a shorter mean time of mortality ( $4.14 \pm 0.04$ days) compared to the plant-derived isolate (4.58 \pm 0.08 days) $\left(\operatorname{LSD}_{0.05}=0.25\right)$, while the level of overt mycosis recorded with PPRI 7598IN (58.2\%; $n=60$ ) was significantly higher $\left(\mathrm{LSD}_{0.05}=6.49\right)$ compared with PPRI 7598PL $(47.9 \% ; n=55)$ (Fig. 3). 
Table 1. Wheat cultivars, their pedigree and general characteristics.

\begin{tabular}{|c|c|c|c|c|c|}
\hline \multirow{2}{*}{$\begin{array}{l}\text { General } \\
\text { characteristics }\end{array}$} & \multicolumn{5}{|c|}{ Cultivars } \\
\hline & Tugela & Elands & Gariep & Kariega & Baviaans \\
\hline $\begin{array}{l}\text { Breeding history } \\
\text { and pedigree } \\
\text { origin }^{*}\end{array}$ & Kavkaz/Jaral & $\begin{array}{l}\text { PI137739/*4Molopo } \\
\text { (77) }\end{array}$ & $\begin{array}{l}\text { PI137739/*4Molopo } \\
\text { (20) }\end{array}$ & $\begin{array}{l}\text { SST44// K4500 } \\
\text { /SAPSUCKER"S" }\end{array}$ & $\begin{array}{l}\text { Queen } \\
\text { Fan(A50)/4/Jup/Emu"S"// } \\
\text { Gjo"S"/3/Kvz/K4500L-6-A- } \\
4\end{array}$ \\
\hline Agronomic traits & $\begin{array}{l}\text { High yield } \\
\text { Good straw } \\
\text { strength }\end{array}$ & $\begin{array}{l}140 \text { days to flowering } \\
\text { Good straw strength } \\
\text { Good kernel attachment }\end{array}$ & $\begin{array}{l}138 \text { days to anthesis } \\
\text { Good straw strength } \\
\text { Good kernel attachment }\end{array}$ & $\begin{array}{l}114 \text { days to flowering } \\
\text { Good straw strength } \\
\text { (similar to Gamtoos) }\end{array}$ & $\begin{array}{l}109 \text { days to anthesis } \\
\text { Good straw strength } \\
\text { (similar to Kariega) }\end{array}$ \\
\hline & $\begin{array}{l}\text { Good kernel } \\
\text { attachment } \\
\text { Susceptible to } \\
\text { PHS }^{\S}\end{array}$ & $\begin{array}{l}\text { Resistant to PHS } \\
\text { High yield potential }\end{array}$ & $\begin{array}{l}\text { Resistant to PHS } \\
\text { High yield potential and } \\
\text { excellent yield stability }\end{array}$ & $\begin{array}{l}\text { Good kernel attachment } \\
\text { Resistant to PHS } \\
\text { yield potential similar to } \\
\text { Gamtoos }\end{array}$ & $\begin{array}{l}\text { Good kernel attachment } \\
\text { Resistant to PHS } \\
\text { High yield potential } \\
\text { similar to Kariega }\end{array}$ \\
\hline RWA resistance & $\begin{array}{l}\text { Susceptibe to all } \\
\text { SA biotypes }\end{array}$ & Resistant to RWASA1^ & Resistant to RWASA1 & $\begin{array}{l}\text { Susceptibe to all SA } \\
\text { biotypes }\end{array}$ & $\begin{array}{l}\text { Susceptibe to all SA } \\
\text { biotypes }\end{array}$ \\
\hline $\begin{array}{l}\text { Disease } \\
\text { resistance }\end{array}$ & $\begin{array}{l}\text { Resistant to } \\
\text { stem and leaf } \\
\text { rust }^{*} \text { (similar to } \\
\text { Tugela - DN) }\end{array}$ & $\begin{array}{l}\text { Moderately resistant to } \\
\text { stem rust; moderately } \\
\text { susceptible to stripe rust } \\
\text { and susceptible to leaf rust }\end{array}$ & $\begin{array}{l}\text { Resistant to stem rust; } \\
\text { susceptible to stripe rust } \\
\text { and leaf rust (at adult } \\
\text { stage) }\end{array}$ & $\begin{array}{l}\text { Susceptible to } 1 \text { of } 5 \text { stem } \\
\text { rust races in } S A^{\#} \text {, } \\
\text { moderately susceptible to } \\
\text { leaf rust and resistant to } \\
\text { stripe rust }\end{array}$ & $\begin{array}{l}\text { Susceptible to } 1 \text { of } 5 \text { stem } \\
\text { rust races in SA, } \\
\text { moderately susceptible to } \\
\text { leaf rust and resistant to } \\
\text { stripe rust }\end{array}$ \\
\hline Production area ${ }^{*}$ & Winter dryland & Winter dryland & Winter dryland & Irrigation \& Spring dryland & Spring dryland \& Irrigation \\
\hline Year released ${ }^{*}$ & 1986 & 1998 & 1995 & 1993 & 2000 \\
\hline
\end{tabular}

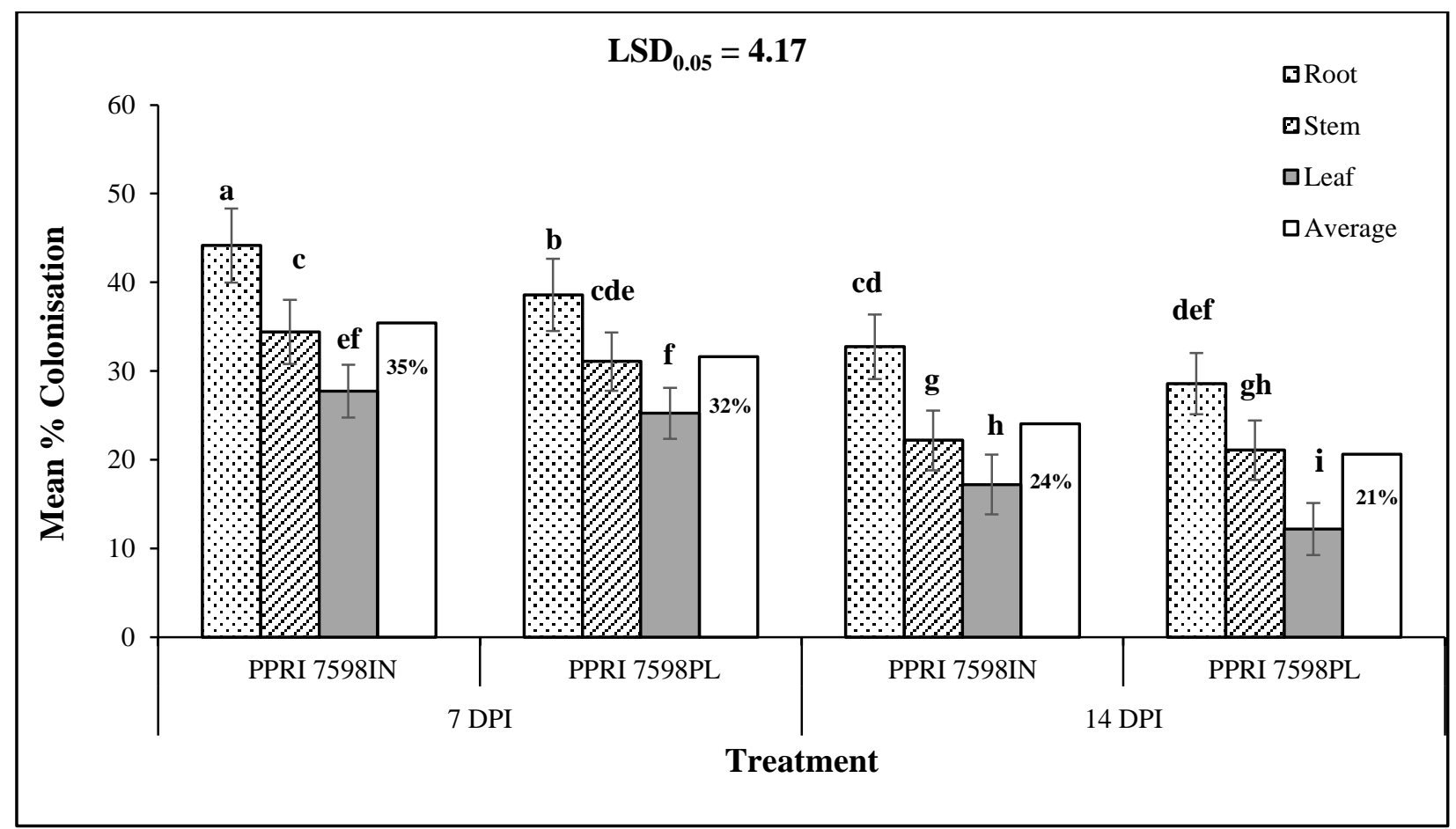

Fig 1. Colonisation of different plant parts by Beauveria bassiana PPRI 7598 isolates at 7 and 14 days post inoculation. Bars (Means $\pm S E M$ ) marked with different letters indicate significant differences at $P<0.05$; $L S D=4.1742$. 
Table 2. Effect of three inoculation techniques on seedling growth of five wheat cultivars (combined) after 21 days.

\begin{tabular}{|c|c|c|c|c|c|c|}
\hline $\begin{array}{l}\text { Inoculation } \\
\text { technique }\end{array}$ & $\begin{array}{c}\text { Fresh shoot } \\
\text { biomass } \\
\text { (g) }\end{array}$ & $\begin{array}{l}\text { Dry shoot } \\
\text { biomass } \\
\text { (g) }\end{array}$ & $\begin{array}{c}\text { Fresh root } \\
\text { biomass } \\
\text { (g) }\end{array}$ & $\begin{array}{l}\text { Root } \\
\text { length } \\
(\mathrm{cm})\end{array}$ & $\begin{array}{l}\text { Shoot } \\
\text { height } \\
(\mathrm{cm})\end{array}$ & Grand mean \\
\hline Seed imbibition & $80.03 b^{1}(2)^{2}$ & $45.25 b(3)$ & $235.23 a(1)$ & $48.85 b(2)$ & $29.47 a b(2)$ & $87.77 \pm 42.22(1)$ \\
\hline Soil drenching & $76.96 b(3)$ & $75.35 b(2)$ & $39.48 b(2)$ & $32.20 c(3)$ & $25.84 b(3)$ & $49.97 \pm 12.20(3)$ \\
\hline $\begin{array}{l}\text { Leaf } \\
\text { spraying }\end{array}$ & $92.96 a(1)$ & 152.63a (1) & $35.88 \mathrm{~b}(3)$ & 56.30a (1) & $32.53 a(1)$ & $74.06 \pm 25.04(2)$ \\
\hline $\mathrm{LSD}_{0.05}$ & 9.10 & 33.95 & 23.32 & 6.74 & 5.99 & - \\
\hline Grand mean & $83.32 \pm 4.9$ & $91.08 \pm 31.98$ & $103.53 \pm 65.86$ & $45.78 \pm 7.12$ & $29.28 \pm 1.93$ & $70.60 \pm 15.79$ \\
\hline
\end{tabular}

${ }^{1}$ Means \pm SEM (\% increase over controls) within columns followed by the same letter are not significantly different at the $5 \%$ test level, ${ }^{2}$ Performance ranking within a given growth parameter (column) in parenthesis

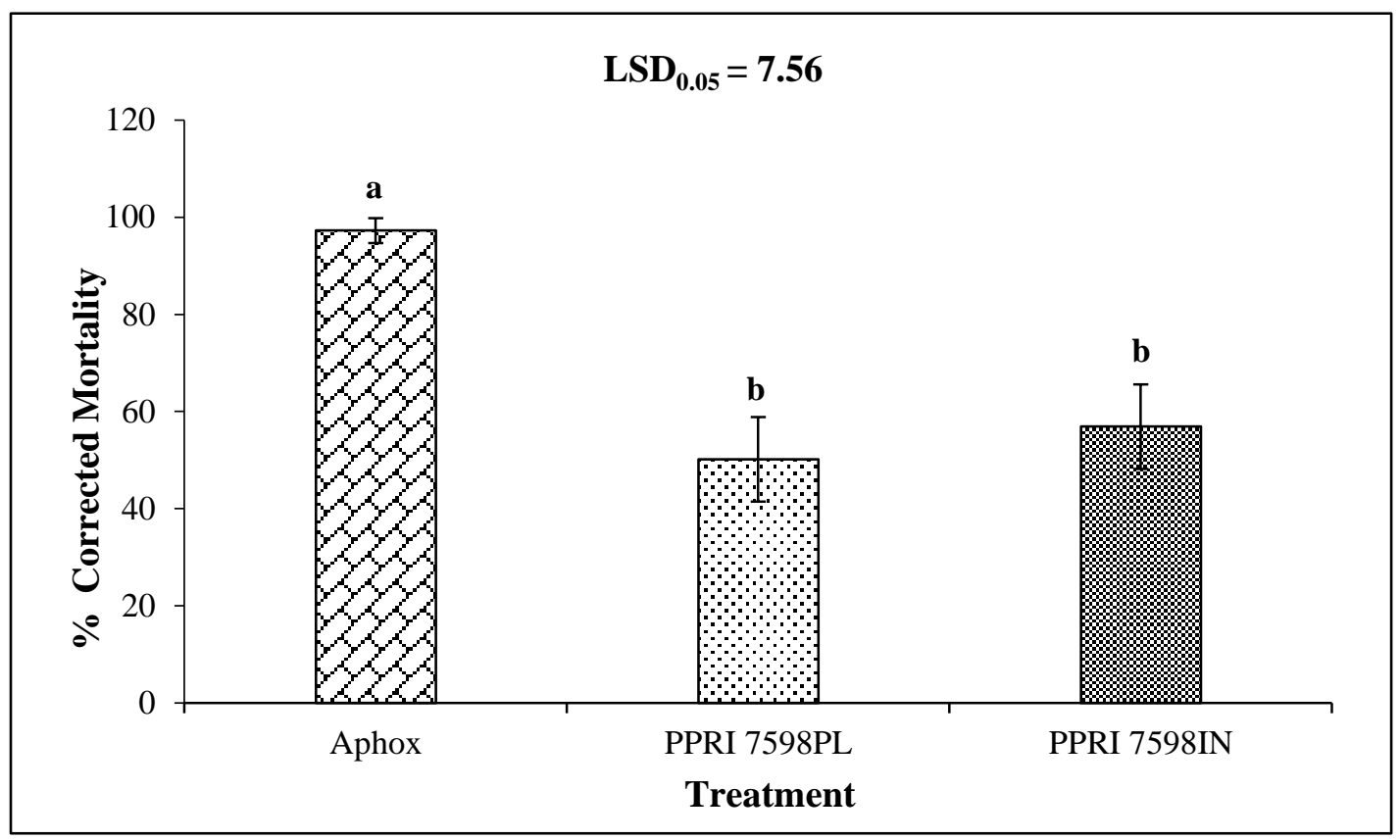

Fig 2.Mean percentage Schneider-Orelli - corrected mortality of the Russian wheat aphid 7 days post inoculation, caused by the chemical standard, Aphox and two PPRI 7598 isolates. Bars (Means \pm SEM) marked with different letters indicate significant differences at the $P$ value $<0.05 ; \mathrm{LSD}=7.562$.

Table 3. Cultivar growth response at 21 days following inoculation (three techniques, combined) with Beauveria bassiana PPRI 7598 IN.

\begin{tabular}{|c|c|c|c|c|c|c|}
\hline Cultivar & $\begin{array}{c}\text { Fresh shoot } \\
\text { biomass } \\
\text { (g) }\end{array}$ & $\begin{array}{l}\text { Dry shoot } \\
\text { biomass } \\
\text { (g) }\end{array}$ & $\begin{array}{c}\text { Fresh root } \\
\text { biomass } \\
\text { (g) }\end{array}$ & $\begin{array}{l}\text { Root } \\
\text { length } \\
(\mathrm{cm})\end{array}$ & $\begin{array}{l}\text { Shoot } \\
\text { height } \\
(\mathrm{cm})\end{array}$ & $\begin{array}{l}\text { Grand } \\
\text { mean }\end{array}$ \\
\hline Tugela & $86.84 a b^{1}(2)^{2}$ & $61.98 b(5)$ & $70.07 b c(3)$ & 50.39a (1) & $26.63 b(4)$ & $59.18 \pm 10.07(5)$ \\
\hline Kariega & 77.06b (5) & $89.14 b(3)$ & 260.37a (1) & $47.88 \mathrm{a}(3)$ & $25.22 b(5)$ & $99.93 \pm 41.64$ (1) \\
\hline Baviaans & $89.44 a(1)$ & $93.97 b(2)$ & $63.78 b c(4)$ & $37.59 b(5)$ & $28.87 a b(3)$ & $62.73 \pm 13.17(4)$ \\
\hline Elands & $77.22 b(4)$ & $139.75 a(1)$ & $42.40 c(5)$ & 42.97ab (4) & $29.62 \mathrm{ab}(2)$ & $66.39 \pm 19.97(2)$ \\
\hline Gariep & $86.03 a b(3)$ & $70.56 b(4)$ & $81.04 b(2)$ & $50.10 a(2)$ & $36.08 \mathrm{a}(1)$ & $64.76 \pm 9.46(3)$ \\
\hline $\mathrm{LSD}_{0.05}$ & $11.75^{3}$ & $43.83^{4}$ & $30.11^{4}$ & $8.71^{4}$ & $7.74^{3}$ & - \\
\hline Grand mean & $83.32 \pm 2.58$ & $91.08 \pm 13.51$ & $103.53 \pm 39.71$ & $45.79 \pm 2.44$ & $29.28 \pm 1.89$ & $70.6 \pm 6.91$ \\
\hline
\end{tabular}

${ }_{2}^{1}$ MeanstSEM (\% increase over controls) within columns followed by the same letter are not significantly different at the $5 \%$ test level ${ }^{2}$ Performance ranking within a given growth parameter (column) in parenthesis ${ }^{3}$ Fisher's unprotected LSD tes
${ }^{4}$ Fisher's protected LSD test 


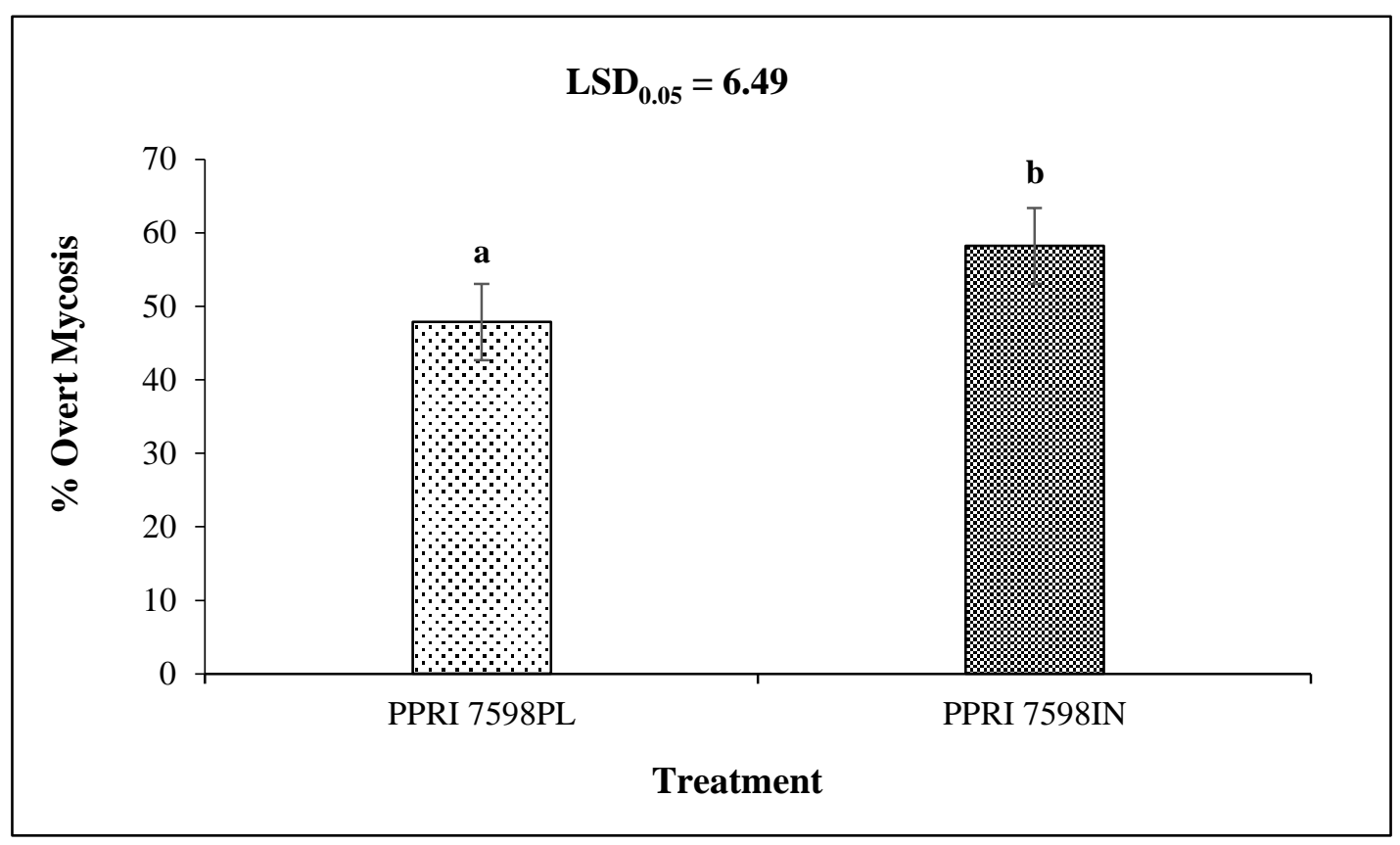

Fig 3. Mean percentage overt mycosis by the two PPRI 7598 backgrounds 7 DPI. Bars (Means $\pm S E M)$ marked with different letters indicate significant differences at $P$ value $<0.05$; $L S D=6.488$.

\section{Discussion}

Successful colonisation of roots, stems and/or leaves, following seed imbibition with $B$. bassiana, has been reported for wheat (Russo et al., 2015; Sánchez-Rodríguez et al., 2015; Sánchez-Rodríguez et al., 2018), broad bean (Jaber and Enkerli, 2016), sorghum (albeit only in sterile soil; Tefera and Vidal, 2009) and also for cotton, tomato and snap bean, following topical seed inoculation with dry conidia (Ownley et al., 2008). Similar results were found in our study, although compared with other plant parts, a significantly higher level of endophytism was observed in roots for PPRI $7598 \mathrm{IN}$ and -PL, at both 7 and 14 DPI. Clearly, the uptake and systemic spread of endophytic $B$. bassiana (Behie et al., 2015) via seed treatment, holds significant potential as an economical and practical inoculation method; especially for wheat, where seeding volumes range from $15-30 \mathrm{~kg}$ per hectare (ARC-Small Grain, 2018). Although the current study did not measure endophytic persistence beyond 14 days, fungal colonisation of host plants at the early developmental stage may provide a crucial competitive advantage to these plants, potentially improving their ability to cope with stress and/or utilise limited resources (Hubbard et al., 2013; Bokati et al., 2016). In South Africa, wheat cultivated under dryland conditions in the summer rainfall region, is typically sown in the winter months of May-July and plants emerge during June-August, just prior to the arrival of spring rains in late September/early October, onwards. During and shortly after seedling emergence, soil moisture levels (residual from the preceding summer season) continue to drop amidst increasing temperatures. Endophytic colonisation of such seedlings, with special emphasis on improved root development (on average, 65\% increase in fresh root biomass among the three dryland-production cultivars tested in this study) may hold significant advantages; a notion supported by the findings in our plant-response trials. For all five plant growth parameters measured within 42-45 DPI, fungus-treated plants significantly outperformed control plants. Similarly, positive growth response with $B$. bassiana-inoculated wheat was reported by Gurulingappa et al. (2010) and more recently by recording an impressive $40 \%$ increase in wheat grain yield (Sánchez-Rodríguez et al., 2018). Using only one wheat cultivar (Chinese Spring) and essentially the same techniques and conidial concentrations as in this study, Sánchez-Rodríguez et al. (2018) reported superior colonisation and subsequent growth responses with seed dressing compared with controls. A similar 'cultivar-specific' reaction may be involved with cultivar Kariega, showing a very high affinity towards seed treatment with $B$. bassiana in the current study. An interesting observation from the studies by Quesada-Moraga et al. (2014) and Sánchez-Rodríguez et al. (2018), is vertical transmission of $B$. bassiana. This phenomenon could hold potential for suppression of seed-related diseases like Fusarium head blight (FHB), an important wheat disease not only in South Africa, but globally (Dean et al., 2012). According to Rabiey and Shaw (2016), application of the root-colonising endophyte, Piriformospora indica (Sebacinaceae) to wheat, reduced FHB disease severity and incidence by $70 \%$, while lowering mycotoxin (DON) concentration of winter and spring wheat samples by 70 and $80 \%$, respectively. The approach also increased aboveground biomass, 1000-kernel weight and total grain weight. Although endophytic Beauveria is known to suppress damping-off in cotton (Griffin et al., 2005; Griffin, 2007), bacterial blight in tomato (Ownley et al., 2008), zucchini yellow mosaic virus in squash (Jaber and Salem, 2014) and downy mildew in grapevines (Jaber, 2015), its biocontrol potential against FHB in wheat is yet to be explored.

Artificial introduction of $B$. bassiana as an endophyte in wheat or any other host plant implies subjecting the fungus to a different growing environment in terms of nutrients, $\mathrm{pH}$, phytochemicals, etc. Generally, passage of an EPF through an insect host is seen as advantageous, i.e. a means of either enhancing or restoring virulence (Song and Feng, 2011). However, the effect on virulence following passaging 
through a wheat host plant has remained largely unexplored, with this study being the first to report on such endeavour. Use of plant-passaged conidia caused slightly lower aphid mortality, a significantly longer mean time of mortality as well as a lower level of overt mycosis (sporulation of cadavers), suggesting some level of impediment demonstrated by the plant-derived isolate. Relatively, the insect-derived isolate outcompeted the plantderived isolate in all aphid mortality parameters measured. Our findings underscored several positive aspects associated with endophytic B. bassiana in wheat. Additional to our study, endophytic $B$. bassiana is also being explored locally (in South Africa) in crops like sugarcane (Memela, 2014; Memela et al., 2017) and 'Rooibos' (Hatting, 2017), an indigenous shrub from which tea is made through leaf fermentation. Clearly, expanding the use of B. bassiana (and other EPFs) from a topically applied bioinsecticide to systemic bioinsecticide, with potential disease suppressive (Jaber and Ownley, 2018) and plant growth promoting attributes (in addition to wheat, see also Sasan and Bidochka, 2012; Lopez and Sword, 2015; Jaber and Enkerli, 2017), creates new and exciting IPM possibilities.

\section{Materials and Methods}

\section{Plant materials}

Seeds of three dryland-production bread wheat cultivars (Tugela, Elands and Gariep) and two irrigated-production cultivars (Kariega and Baviaans), all developed by ARC-Small Grain, Bethlehem, South Africa, were used in this study (Table 1). Seed surface sterilisation based on the Akello and Sikora (2012) procedure was performed prior to seed treatment. Following sterilisation, seeds were dried in the laminar flow hood for 30 minutes and later immersed in a $B$. bassiana fungal suspension at the concentration of $1 \times 10^{8}$ conidia $\mathrm{ml}^{-1}$ for $18-24 \mathrm{hrs}$ (Dhingra and Sinclair, 1995). Each cultivar was treated separately, with the "IN-" and "PLreisolated" B. bassiana strain PPRI 7598. Control seeds were soaked in sterile distilled water with $0.01 \%$ Break Thru surfactant for 18-24 hours. During the soaking period, seeds were maintained on an orbital shaker at room temperature (Dhingra and Sinclair, 1995). Inoculated and control seeds were later dried on sterile paper towels in a laminar flow hood for three hours prior to planting. Inoculated and control seeds were planted in sterilised $295 \mathrm{ml}$ plastic pots containing sterile soil $\left(\mathrm{pH}_{[\mathrm{KCl}]}=4.8, \mathrm{P}=5.0 \mathrm{mg} / \mathrm{kg}, \mathrm{K}=125.0\right.$ $\mathrm{mg} / \mathrm{kg}, \mathrm{Ca}=600 \mathrm{mg} / \mathrm{kg}, \mathrm{Mg}=203 \mathrm{mg} / \mathrm{kg}$, Acid saturation = $4.2 \%$ ), heat-treated at $91 \pm 1^{\circ} \mathrm{C}$ for $4 \mathrm{hrs}$. Plants were grown and maintained under glasshouse conditions of $22 \pm 3 \circ \mathrm{C}, 70$ $\pm 4 \%$ relative humidity $(\mathrm{RH})$ and natural light.

\section{Insect material}

Colonies of $D$. noxia biotype RWASA1 were reared in the ARC-Small Grain insectary unit. An aphid colony was established by infesting clean wheat seedlings (cultivar Tugela) at four-leaf growth stage (Hatting and Wraight, 2007); the populations were then reared in gauze cages in a glasshouse at $22 \pm 3 \circ \mathrm{C}, 40 \pm 4 \% \mathrm{RH}$ and natural light. Aphids were monitored until they reached the adult stage prior to use in bioassays.

\section{Fungal isolates}

The $B$. bassiana fungal isolate, PPRI 7598 , was cultured on $B$. bassiana selective medium amended with $0.55 \mathrm{~g} / \mathrm{L}$ dodine (guanidine) and $0.005 \mathrm{~g} / \mathrm{L}$ chlortetracycline (Sigma - Aldrich, Germany) (Chase et al., 1986). Fungal cultures were incubated in full darkness at $25 \pm 1$ 으 and $60 \pm 10 \% \mathrm{RH}$. Conidia were harvested from 14 day-old cultures using a sterile scalpel and suspended in a sterile aliquot of distilled water with $0.01 \%$ Break Thru surfactant (Polyetherpolymethylsiloxane-copolymer surfactant; Goldschmidt Chemical Corporation, USA). Suspension concentrations were adjusted to $1 \times 10^{8}$ conidia $\mathrm{ml}^{-1}$ using a Nikon Optiphot light microscope (Nikon, Japan) and improved Neubauer Haemocytometer (Neubauer, Germany).

\section{Fungal strain inoculation and re-isolation from insects and plants}

The $B$. bassiana fungal strain PPRI 7598 was inoculated (passaged) through the target insect ( $D$. noxia, via topical inoculation; Inglis et al., 2012) and wheat (T. aestivum, cultivar Tugela) via seed imbibition with a conidial suspension containing $1 \times 10^{8}$ conidia $\mathrm{ml}^{-1}$ using the protocol of Akello and Sikora (2012). The fungus was re-isolated from the two hosts and designated as insect- and plant-derived isolates, "IN" and "PL", respectively.

\section{Treatments}

Endophytic establishment through seed treatment with "IN" versus " $P L$ " recovered isolates in five South African wheat cultivars

The purpose of this experiment was to establish $B$. bassiana isolates as endophytes in South African wheat cultivars, thereby comparing endophytic potential of the insectversus plant- derived isolates. The experiment was arranged as a completely randomised design with five replicates. The treatment design was a split-split plot. The main plot treatments were the cultivars and first subplot was the fungal strains (from the insect and plant derived sources). The second subplot was plant parts (root, stem or leaf). Segments from plant parts (roots, stems and leaves) were excised and surface sterilised according to the method of Bills (1996) and plated on B. bassiana-selective medium based on Sabouraud dextrose agar amended with $1 \%$ yeast extract (SDAY) (SDA Biolab, Merck, Longmeadow, Modderfontein, South Africa), containing $0.55 \mathrm{~g} / \mathrm{L}$ dodine (guanidine) and $5 \mathrm{mg} / \mathrm{L}$ chlortetracycline antibiotic (Chase et al., 1986). A total of 270 treated plant sections ( 9 segments from 3 plant parts $\times 5$ cultivars $\times 2$ observation times) were included in the trial. Four independent trials were conducted, at least seven days apart (total of 13500 plants). Plates with surface sterilised plant sections were incubated at $25 \pm 2^{\circ} \mathrm{C}$ for 7-10 days and evaluated in comparison with the controls.

\section{Effect of three inoculation techniques on five plant growth parameters}

Wheat cultivars were inoculated with $B$. bassiana best performing isolate (insect-derived isolate) from the previous 
assay, employing three different inoculation techniques, viz. seed imbibition, soil drenching and leaf spraying. A volume of $5 \mathrm{ml}$ of a $1 \times 10^{8}$ conidia ml ${ }^{-1}$ suspension was administered in each pot for two inoculation techniques (except for seed imbibition). Seed imbibition was performed as in the previous assay on 1125 treated plants ( 75 pots $\times 3$ plants per pot $\times 5$ cultivars) and 1125 control plants (imbibition of water plus $0.01 \%$ Break-Thru, only). Another batch of 150 pots ( 75 treatment +75 control) was also included in the soil drenching treatment. The desired conidia $\mathrm{ml}^{-1}$ suspension was spread directly onto the soil around the stem-base of three 14-day old seedlings (approximately $1.7 \mathrm{ml}$ per seedling) soaking the roots in each pot, using a $5 \mathrm{ml}$ stepper syringe (Socorex ${ }^{\mathrm{TM}} 411$ Stepper). For leaf spraying, leaves of 1125 plants (14-day old) were sprayed to a point of run-off (Rondot and Reineke, 2018) with the same suspension concentration as above using a hand-held atomizer. Control plants (1125) were sprayed with water plus $0.01 \%$ Breakthru, only. Prior to spraying, stem bases and the soil surfaces of treated pots were covered with aluminum foil to prevent inoculation of these areas (Posada et al., 2007). Plants were maintained under glasshouse conditions at 25 $\pm 2 \stackrel{\circ}{\circ}, 40 \pm 5 \% \mathrm{RH}$ and natural light for $42-45$ days. All plants were evaluated for five plant growth parameters: shoot height, root length, fresh shoot biomass, fresh root biomass and dry shoot biomass. Three independent trials were conducted at least seven days apart. The experimental design was organized as completely randomized with five replicates, while the treatment design was a split-plot with a two factorial design as the main plot. The two factors were cultivars with five levels and inoculation techniques with three levels. The subplot factor was fungal strains with two levels (fungus-treated and control).

Virulence of Beauveria bassiana PPRI 7598 to RWA following passage and re-isolation from an insect ("IN") versus plant ("PL") host

Bioassays were performed with B. bassiana $7598 \mathrm{IN}$ and $-\mathrm{PL}$ according to the assay methodology of Hatting and Wraight (2007). Treatments included the two B. bassiana isolates (at $1 \times 10^{8}$ conidia $\mathrm{ml}^{-1}$ ) and a chemical standard, Aphox WG (active: pirimicarb), at a concentration of $0.5 \mathrm{~g} / \mathrm{L}$. Agerelated adult apterae aphids (biotype RWASA1) were sourced from the ARC-Small Grain insectary with 5 replicate groups of 20 aphids each (100 aphids) allocated to each treatment ( $\times 3$ ) and control (total 400 aphids). Control aphids were sprayed with sterile water containing $0.01 \%$ BreakThru surfactant, only. All treatments and control were sprayed with $5 \mathrm{ml}$ aliquots inside a Burgerjon precision spray tower (Burgerjon, 1956). During spraying, a Petri dish containing $1.5 \%$ water agar was placed adjacent to the aphids on the same radial dimension to quantify the actual number of conidia deposited per $\mathrm{mm}^{2}$. As per protocol, inoculated aphids were maintained on wheat seedlings (cultivar Tugela; 4-leaf stage) under glasshouse conditions at $25 \pm 2 \stackrel{\circ}{ } \mathrm{C}, 40 \pm 5 \% \mathrm{RH}$ and natural light for 7 days postinoculation.

Mortality was assessed daily for the duration of the assay and all dead aphids collected and placed on $1.5 \%$ water agar and incubated at $22 \pm 3 \circ \mathrm{C}$ in total darkness to facilitate the development of mycosis (external sporulation on cadavers). Three independent series of assays were conducted seven days apart.

\section{Statistical analyses}

Mortality data were corrected according to the Schneider Orelli formula. The homogeneity of four trial variances were verified by Levene's test (Levene, 1960). The normality of the standardized residuals was confirmed using Shapiro-Wilk test (Shapiro and Wilk, 1965). The data of the combined trials were subjected to analysis of variance (ANOVA) using General Linear Models Procedure (PROC GLM) of SAS software (Version 9.4; SAS Institute Inc, Cary, USA). Observations over days were combined in a split-plot analysis of variance with day as sub-plot factor (Little and Hills , 1978). A combined ANOVA for the cumulative mortality over 7 days was performed. Fisher's protected least significant difference (LSD) was calculated at the $5 \%$ level to compare treatment means (Ott and Longnecker, 2001). A probability level of $5 \%$ was considered significant for all tests.

\section{Conclusion}

All five South African wheat cultivars tested were amenable to $B$. bassiana endophytic establishment, with levels ranging from $21 \%$ (cultivar Elands) to $34 \%$ (cultivar Baviaans). Similar to other published reports, endophytic B. bassiana also promoted overall plant growth in our study. Considering five growth parameters, B. bassiana-treated plants outperformed control plants by $71 \%$, on average. Pathogenicity of $B$. bassiana to RWA was retained following passaging and re-isolation from a wheat host plant, supporting the notion of incorporating $B$. bassianaendophytism as IPM component. Futher studies on the interaction of host plant resistance and $B$. bassianaendophytism are warranted, especially in light of new RWA biotype development. Whether naturally present or artificially induced, B. bassiana-endophytism appears beneficial within a wheat cropping system.

\section{Acknowledgements}

Authors thank Joyce Mebalo and Emma Mollo from the Agricultural Research Council of South Africa-Small Grain for rendering technical assistance in this study. We acknowledge $\mathrm{Dr}$ David Shapiro-Ilan (U.S Department of Agriculture, USA) and Professor Travis Glare (Lincoln University, New Zealand) for preliminary review of this paper before it was resubmitted to the journal. This work was financially supported by the Professional Development Programme of the Department of Science and Technology and the National Research Foundation (DST-NRF) (Grant No. 96715) and Agricultural Research Council (ARC - Small Grain).

\section{References}

Akello J and Sikora R (2012) Systemic acropedal influence of endophyte seed treatment on Acyrthosiphon pisum and Aphis fabae offspring development and reproductive fitness. Biol Control. 61:215-221. 
ARC-Small Grain (1998) Guidelines for wheat production in the summer rainfall region. Agricultural Research Council, South Africa.

ARC-Small Grain (2018) Guidelines for the Production of Small Grains in the Summer Rainfall Region. Agricultural Research Council, South Africa. ISBN: 978-0-621-46055-8. Available at http://www.arc.agric.za/arc-sgi/Pages/ARCSGI-Homepage.aspx. Accessed on 22 October 2018.

Behie SW and Bidochka MJ (2014) Ubiquity of insect-derived nitrogen transfer to plants by endophytic insectpathogenic fungi: an additional branch of the soil nitrogen cycle. Appl Environ Microbiol. 80: 1553-1560.

Behie SW, Jones SJ and Bidochka MJ (2015) Plant tissue localization of the endophytic insect pathogenic fungi Metarhizium and Beauveria. Fungal Ecol. 13: 112-119.

Bills GF (1996) Isolation and analysis of endophytic fungal communities from woody plants. In: Redlin SC, Carris LM (eds.) Endophytic Fungi in Grasses and Woody Plants: Systematics, Ecology and Evolution. APS Press, St. Paul, Minnesota, USA. 31-65.

Bokati D, Herrera J and Poudel R (2016) Soil influences colonisation of root-associated fungal endophyte communities of maize, wheat, and their progenitors. J Mycol. Article ID 8062073: 1-9.

Burgerjon A (1956) Pulvérisation et poudrage au laboratoire par des préparations pathogènes insecticides. Annales Epiphytes 7: 677-686.

Busby PE, Ridout $M$ and Newcombe G (2016) Fungal endophytes: modifiers of plant disease. Plant Mol Biol. 90: 645-655.

Chase AR, Osborne LS and Ferguson VM (1986) Selective isolation of the entomopathogenic fungi Beauveria bassiana and Metarhizium anisopliae from an artificial potting medium. Florida Entomol. 69: 285-292.

Coale MJ (2017) The Economic Benefits of the South African Agricultural Research Council's Wheat Breeding Program: 1992-2015. PhD Thesis, University of Arkansas, Fayetteville, USA. Available at http://scholarworks.uark.edu/etd/2600. Accessed on 2 May 2019.

Comby M, Lacoste S, Baillieu F, Profizi C and Dupont J (2016) Spatial and temporal variation of cultivable communities of co-occurring endophytes and pathogens in wheat. Front Microbiol. 7: 1-16.

Crous PW, Petrini O, Marais GF, Pretorius ZA and Rehder F (1995) Occurrence of fungal endophytes in cultivars of Triticum aestivum L. in South Africa. Mycoscience 36: 105111.

Dean R, Van Kan JAL, Pretorius ZA, Hammond-Kosack KE, Di Pietro A, Spanu PD, Rudd JJ, Dickman M, Kahmann R, Ellis J and Foster GD (2012) The Top 10 fungal pathogens in molecular plant pathology. Mol Plant Pathol. 13: 414-430.

Dhingra OD and Sinclair JB (1995) Basic plant pathology methods ( $2^{\text {nd }}$ edn). CRC Press, Boca Raton, Florida, USA. 1448.

Dingle J and McGee PA (2003) Some endophytic fungi reduce the density of pustules of Puccinia recondita $\mathrm{f}$. $\mathrm{sp}$. tritici in wheat. Mycol Res. 107: 310-316.

Fuxa JR (1998) Environmental manipulation for microbial control of insects. In: Barbosa P (ed.) Conservation Biological Control. Academic Press, San Diego, USA. 255268.
Griffin M, Ownley B, Klingeman W and Pereira R (2005) Biocontrol of Rhizoctonia damping-off of cotton with endophytic Beauveria bassiana. Phytopathology 95: S36.

Griffin MR (2007) Beauveria bassiana, a cotton endophyte with biocontrol activity against seedling disease. PhD Dissertation. University of Tennessee, Knoxville, USA. 163.

Grudzinska-Sterno M, Yuen J and Stenlid J (2016) Fungal communities in organically grown winter wheat affected by plant organ and development stage. Eur J Plant Pathol. 146: 401-417.

Gurulingappa P, Sword GA, Murdoch G and McGee PA (2010) Colonisation of crop plants by fungal entomopathogens and their effects on two insect pests when in planta. Biol Control 55: 34-41.

Hatting JL (2002) Fungal Parasitism of Cereal Aphids in South Africa. PhD Thesis. University of Natal, Pietermaritzburg, South Africa. 185.

Hatting JL (2017) Major insect pests and their natural enemies associated with cultivation of Rooibos, Aspalathus linearis (Burm. f.) R. Dahlgren, in South Africa: a review. S Afr J Bot. 110: 118-123.

Hatting JL and Wraight SP (2007) Optimizing bioassay precision, with special reference to the Aphididae and Aleyrodidae. In: Ekesi S, Maniania NK (eds.) Use of Entomopathogenic Fungi in Biological Pest Management. Research Signpost, India. 197-237.

Hatting JL, Humber RA, Poprawski TJ and Miller RM (1999) A survey of fungal pathogens of aphids from South Africa, with special reference to cereal aphids. Biol Control 16: 112.

Hatting JL, Moore SD and Malan AP (2018) Microbial control of phytophagous invertebrate pests in South Africa: current status and future prospects. J Invertebr Pathol. https://doi.org/10.1016/j.jip.2018.02.004.

Hatting JL, Poprawski TJ and Miller RM (2000) Prevelances of fungal pathogens and other natural enemies of cereal aphids (Homoptera: Aphididae) in wheat under dryland and irrigated conditions in South Africa. BioControl 45: 179-199.

Hatting JL, Wraight SP and Miller RM (2004) Efficacy of Beauveria bassiana (Hyphomycetes) for control of Russian wheat aphid (Homoptera: Aphididae) on resistant wheat under field conditions. Biocontrol Sci Technol. 14: 459-473.

Howe AG, Ravn HP, Jensen AB and Meyling NV (2016) Spatial and taxonomical overlap of fungi on phylloplanes and invasive alien ladybirds with fungal infections in tree crowns of urban green spaces. FEMS Microbiol Ecol. 92: doi: 10.1093/femsec/fiw143.

Hsu JC (1996) Multiple comparisons: theory and methods. Chapman \& Hall, London. 291.

Hubbard M, Germida JJ and Vujanovic V (2013) Fungal endophytes enhance wheat heat and drought tolerance in terms of grain yield and second-generation seed viability. J Appl Microbiol. 116: 109-122.

Inglis GD, Enkerly E and Goettel MS (2012) Laboratory techniques used for entomopathogenic fungi: Hypocreales. In: Lacey LA (ed.) Manual of Techniques in Invertebrate Pathology ( $2^{\text {nd }}$ edn). Academic Press, Elsevier, London. 189-253.

Jaber LR (2015) Grapevine leaf tissue colonisation by the fungal entomopathogen Beauveria bassiana sensu lato and its effect against downy mildew. BioControl 60: 103112. 
Jaber LR and Enkerli J (2016) Effect of seed treatment duration on growth and colonisation of Vicia faba by endophytic Beauveria bassiana and Metarhizium brunneum. Biol Control 103: 187-195.

Jaber LR and Enkerli J (2017) Fungal entomopathogens as endophytes: can they promote plant growth? Biocontrol Sci Technol. 27: 28-41.

Jaber LR and Ownley BH (2018) Can we use entomopathogenic fungi as endophytes for dual biological control of insect pests and plant pathogens? Biol Control 116: 36-45.

Jaber LR and Salem NM (2014) Endophytic colonisation of squash by the fungal entomopathogen Beauveria bassiana (Ascomycota: Hypocreales) for managing Zucchini yellow mosaic virus in cucurbits. Biocontrol Sci Technol. 24: 10961109.

Jankielsohn A (2016) Changes in the Russian wheat aphid (Hemiptera: Aphididae) biotype complex in South Africa. J Econ Entomol. 109: 907-912.

Jankielsohn A (2019) New Russian wheat aphid biotype found in Free State. SA Grain 21: 70-71.

Larran S, Perello A, Simon MR and Moreno V (2002) Isolation and analysis of endophytic microorganisms in wheat (Triticum aestivum L.) leaves. World J Microbiol Biotechnol. 18: 683-686.

Larran S, Perello A, Simon MR and Moreno V (2007) The endophytic fungi from wheat (Triticum aestivum L.). World J Microbiol Biotechnol. 23: 565-572.

Levene $H$ (1960) Robust tests for equality of variances. In: Olkin (ed.) Contributions to probability and statistics. Stanford University Press, Palo Alto, USA. 278-292.

Liao X, Lovett B, Fang W and St Leger RJ (2017) Metarhizium robertsii produces indole-3-acetic acid, which promotes root growth in Arabidopsis and enhances virulence to insects. Microbiology 163: 980-991.

Little TM and Hills FJ (1978) Subplot as repeated observations. In: Agricultural experimentation, design and analysis. John Wiley \& Sons, New York, USA. 125-137.

Lopez DC and Sword GA (2015) The endophytic fungal entomopathogens Beauveria bassiana and Purpureocillium lilacinum enhance the growth of cultivated cotton (Gossypium hirsutum) and negatively affect survival of the cotton bollworm (Helicoverpa zea). Biol Control 89: 53-60.

Marasas C, Anandajayasekeram P, Tolmay V, Martella D, Purchase J and Prinsloo G (1997) Socio-economic impact of the Russian wheat aphid control research program. Southern African Centre for Cooperation in Agricultural and Natural Resources and Training, Gaborone, Botswana. 1-147.

Memela N (2014) Isolation of Beauveria bassiana strains from KwaZulu-Natal as biocontrol agents against the African sugarcane Stemborer Eldana saccharina. MSc Dissertation. University of KwaZulu-Natal, Pietermaritzburg, South Africa. 170.

Memela N, McFarlane S, Conlong D, Rutherford RS and Schmidt S (2017) For and against: towards the use of endophytes for the control of the stalk borer Eldana saccharina (Lepidoptera: Pyralidae) in sugarcane. Paper presented at the 2017 Combined Congress of the Entomological and Zoological Societies of Southern Africa, CSIR International Convention Centre, Pretoria, South Africa, 3-7 July 2017.
Meyling NV and Eilenberg J (2006) Isolation and characterisation of Beauveria bassiana isolates from phylloplanes of hedgerow vegetation. Mycol Res. 110: 188-195.

Meyling NV and Eilenberg J (2007) Ecology of the entomopathogenic fungi Beauveria bassiana and Metarhizium anisopliae in temperate agroecosystems: potential for conservation biological control. Biol Control 43:145-155.

Ott RL and Longnecker M (2001) An introduction to statistical methods and data analysis $\left(5^{\text {th }}\right.$ edn). Duxbury Press, Belmont, California. 1-1152.

Ownley BH, Griffin MR, Klingeman WE, Gwinn KD, Moulton JK and Pereira RM (2008) Endophytic colonisation and plant disease control. J Invertebr Pathol. 98: 267-270.

Posada F, Aime MC, Peterson SW, Rehner SA and Vega FE (2007) Inoculation of coffee plants with the fungal entomopathogen Beauveria bassiana (Ascomycota: Hypocreales). Mycol Res. 111: 748-757.

Prinsloo G, Chen Y, Giles KL and Greenstone MH (2002) Release and recovery in South Africa of the exotic aphid parasitoid Aphelinus hordei verified by the polymerase chain reaction. BioControl 47: 127-136.

Prinsloo GJ and Tolmay VL (2015) Wheat. In: Prinsloo GL, Uys VM (eds.) Insects of cultivated plants and natural pastures in Southern Africa. Entomological Society of Southern Africa, Hatfield, South Africa. 138-151.

Quesada-Moraga E, Lo'pez-Díaz C and Landa BB (2014) The hidden habit of the entomopathogenic fungus Beauveria bassiana: first demonstration of vertical plant transmission. PLoS ONE 9: e89278.

Rabiey M and Shaw MW (2016) Piriformospora indica reduces Fusarium head blight disease severity and mycotoxin DON contamination in wheat under UK weather conditions. Plant Pathol. 65: 940-952.

Rodriguez RJ, White Jr JF, Arnold AE and Redman ARA (2009) Fungal endophytes: diversity and functional roles. New Phytol. 182: 314-330.

Rondot $Y$ and Reineke A (2018) Endophytic Beauveria bassiana in grapevine Vitis vinifera (L.) reduces infestation with piercing-sucking insects. Biol Control 116: 82-89.

Russo ML, Pelizza SA, Cabello MN, Stenglein SA and Scorsetti AC (2015) Endophytic colonisation of tobacco, corn, wheat and soybeans by the fungal entomopathogen Beauveria bassiana (Ascomycota, Hypocreales). Biocontrol Sci Technol. 25: 475-480.

Sánchez-Rodríguez AR, Del Campillo MC and QuesadaMoraga E (2015) Beauveria bassiana: an entomopathogenic fungus alleviates $\mathrm{Fe}$ chlorosis symptoms in plants grown on calcareous substrates. Sci Hort. 197: 193-202.

Sánchez-Rodríguez AR, Raya-Díaz S, Zamarreño AM, GarcíaMina JM, Del Campillo MC and Quesada-Moraga E (2018) An endophytic Beauveria bassiana strain increases spike production in bread and durum wheat and effectively controls cotton leafworm (Spodoptera littoralis) larvae. Biol Control 116: 90-102.

Sasan RK and Bidochka MJ (2012) The insect pathogenic fungus Metarhizium robertsii (Clavicipitaceae) is also an endophyte that stimulates plant root development. American J Bot. 99: 101-107. 
Shapiro SS and Wilk MB (1965) An analysis of variance test for normality (complete samples). Biometrika 52: 591-611.

Smit HA, Tolmay VL, Barnard A, Jordaan JP, Koekemoer FP, Otto WM, Pretorius ZA, Purchase JL and Tolmay JPC (2010) An overview of the context and scope of wheat (Triticum aestivum) research in South Africa from 1983 to 2008. S Afr J Plant Soil 27: 81-96.

Smith CM and Chuang WP (2014) Plant resistance to aphid feeding: behavioral, physiological, genetic and molecular cues regulate aphid host selection and feeding. Pest Manag Sci. 70: 528-540.

Song TT and Feng MG (2011) In vivo passages of heterologous Beauveria bassiana isolates improve conidial surface properties and pathogenicity to Nilaparvata lugens (Homoptera: Delphacidae). J Invertebr Pathol. 106: 211216.

Sunderland KD, Chambers RJ and Carter OCR (1988) Potential interactions between varietal resistance and natural enemies in the control of cereal aphids. In: Cavallora R, Sunderland KD (eds.) Integrated Crop Protection in Cereals. A.A. Balkema, Rotterdam, Netherlands. 41-56.
Tefera T and Vidal S (2009) Effect of inoculation method and plant growth medium on endophytic colonisation of sorghum by the entomopathogenic fungus Beauveria bassiana. BioControl 54: 663-669.

Vega FE (2008) Insect pathology and fungal endophytes. J Invertebr Pathol. 98: 277-279.

Vega FE (2018) The use of fungal entomopathogens as endophytes in biological control: a review. Mycologia 110: 4-30.

Vujanovic V, Mavragani D and Hamel C (2012) Fungal communities associated with durum wheat production system: a characterization by growth stage, plant organ and preceding crop. Crop Prot. 37: 26-34.

Yates AD and Michel A (2018) Mechanisms of aphid adaptation to host plant resistance. Curr Opin Insect Sci. 26: 41-49.

Zimmermann G (2007) Review on safety of the entomopathogenic fungi Beauveria bassiana and Beauveria brongniartii. Biocontrol Sci Technol. 17: 553596. 